\title{
Current problems of juvenile labour protection in the conditions of globalization
}

\author{
Pavel Ceniga ${ }^{1, *}$, Viera Sukalova ${ }^{1}$ \\ ${ }^{1}$ University of Zilina, Faculty of Operation and Economics of Transport and Communications, \\ Department of Economics, Univerzitna 1, 01026 Zilina, Slovakia
}

\begin{abstract}
.
Research background: Over the past years, employment and conditions of work have changed considerably; labour market is more flexible what enables enterprises to react faster to changing market requirements. Labour rules make it easier to hire and fire workers. A special category of employees includes juveniles who are covered by increased legal protection; a juvenile employee is an employee under 18 years of age. Work is an important part of every person. Many adolescents want to raise funds to provide for the basic necessities of life, but also to meet the needs of self-realization, socialization and creativity. Young people are regulated by many laws that contain prohibitions and obligations; employers are obliged to create favourable conditions for the all-round development of the physical and mental abilities of juvenile workers also by special adjustment of their working conditions.

Purpose of the article: The article is focused on the analysis of current possibilities and specific conditions of employment of juveniles, identification of problems in the field of employment protection of juveniles in their employment as well as in the performance of work in dual education and proposal of systemic measures for practice.

Methods: The method of analysis, synthesis, deduction, interview and questionnaires were used in the research.

Findings \& Value added: The ever-increasing demands on businesses in a globalized world require a more skilled workforce that is able to contribute to and adapt to technological change with new models of work organization. In connection with this, it is necessary to pay attention to the employment of juveniles, their specific conditions at work and in training for future occupations and elimination of risks.
\end{abstract}

Keywords: juvenile employee; labour protection; legislative rules, risk

JEL Classification: $J 24 ; J 28$

\footnotetext{
* Corresponding author: pavel.ceniga@,fpedas.uniza.sk
} 


\section{Introduction}

New economy in era of globalization has implications for the world of work - organization of work, working time and also for the workers and their private life. Changes in work are connected with changes in social life; new age brings new opportunities for people but also new risks at work. Over the past years, employment and conditions of work have changed considerably. Labour markets have become more flexible; this brings both advantage and disadvantages to employers and workers alike. New work conditions, work organization and technology bring also new risks at work and new requirements in the field of labour protection. An important branch of law affecting the state's economy is labour law. [1] In the twenty-first century, the majority of the working population of the European Union and the world still work in the form of dependent work. The main task of labour law in connection with the current economic order of Europe and the world is to optimize the relationship between capital and the factors of labour so that this connection meets the needs of capital and does not conflict with the human dignity of employees. In general, the term safety and health at work is defined as the state of working conditions that exclude the impact of dangerous and harmful factors of the work process on employees. [2] A new approach to occupational safety requires a systemic approach aimed at preventing the negative aspects - preventing the consequences of accidents. Safety and health protection at work thus becomes in the company not only a matter of management but also of employees. At present, a holistic approach is being promoted in companies with regard to individual areas of work, including psychosocial factors and well-being at work. A particular problem of labour protection is the work of pupils and students. This area of work is not exactly statistically chartered by but still causing considerable practical problems and serious risks to young workers. A juvenile employee is an employee under the age of 18. Juveniles have the right to vocational training and to provide working conditions that enable them to develop their physical and mental abilities. One of the options offered by many secondary vocational schools is to return to dual education. From the point of view of labour protection, the temporary activity of juveniles is also important. Our paper is focused on the analysis of current problems of employment of juveniles; the method of analysis, synthesis, deduction, interview and questionnaire were used in the research.

\section{Research methodologies}

The methodology of research includes: literature review; desk review (to analyse secondary data, to research the latest theoretical and practical developments in management of safety work). Primary data were collected by questionnaire and semi - structured interview. Anonymous questionnaire was sent to 300 adolescents, 258 respondents completed it. A survey was performed in 2019; through methods of data collection, analysis, synthesis, comparison, deduction and induction, we were able to better know and understand what problems and experiences juvenile employees have in relation to work in their part-time work and during dual education. Proposals for measures to eliminate shortcomings in the employment of juveniles create solutions to current problems in the field of labour protection.

\section{Selected aspects of labour protection}

We call labour law a set of legal norms that regulate relations between persons in the performance of human work. The basic legal regulation for the rules of work is Act no. 
311/2001 Coll. Labour Code as amended. The provisions of the valid legislation in relation to the employment of juveniles are as follows: - Government Regulation no. 286/2004 Coll. on the list of works and workplaces prohibited by juvenile employees; Act no. 245/2008 Coll. on upbringing and education; Act no. 124/2006 Coll. on safety and health protection at work; Act No. 126/2006 Coll. on Public Health and on Amendments to Certain Acts, and others. The area where there is a conflict between the subjects of labour law, employees and employers is called the labour market. The demand for work is represented by a group of employers and the opposite of the demand, i.e. the offers for work are represented by employees. The employment relationship is the dominant and most important employment relationship. . There is dependent work between the employee and the employer on the basis of the relationship between the employee's inferiority and the employer's superiority, the so-called principle of subordination. [3] This employment relationship arises at the earliest from the conclusion of the employment contract. Despite strict employment rules, we still face illegal work. Attention must also be paid to the psychological and social factors of work. Bullying affects at least one-third of the workers through either direct exposure or witnessing, both of which lead to compromised health, and as a result, reduced organizational effectiveness or productivity. [4] At present, the requirements for diversity management and the fight against discrimination in the workplace resonate. We recommend explicitly articulating diversity management and equality principles and commitments in documents such as Human resources management policy; Work order; Collective agreement; OSH policy document. Managing diversity is also a competence ranked between personal and interpersonal skills. This competence involves the need to realize that everything around us in the business world is becoming or is diverse. The competence is described as "The ability to treat, act and work with people fairly regardless of their nationality, race, culture, disability, age or gender. To explain the principles of diversity is the best possible way, to promote equality in processes and opportunities for all. [5] Black work is undesirable social phenomenon not only in Slovakia but occurs in varying degrees in all countries. As it brings many challenges in economic and social fields, deserves more attention by the labour inspection based on knowledge of inspection activities and analyses its own survey and propose solutions to the problem areas of work. The solutions are mainly directed to preventive action of labour inspection in order to enhance the legal awareness of the population and eliminate the incidence.

\subsection{Specifics of employment of juveniles}

A juvenile employee is an employee under the age of 18. The ban on work applies not only to children, I. j. natural persons who have not yet reached the age of 15 , but also persons who have reached the age of 15 but have not yet completed compulsory schooling. Pursuant to the Education Act, compulsory school attendance is ten years and lasts until the end of the school year in which the pupil reaches the age of 16, unless this Act provides otherwise. Adolescents have the right to vocational training and working conditions to develop their physical and mental abilities. One of the options offered by many secondary vocational schools is to return to dual education. Many young people's future successful careers are influenced by many factors; This issue is addressed, for example Culkin (2019) who performed analyses and made estimates regarding percentage of U.S. workers in alternative work arrangements, the last time individuals participated in skill-related education or training, number and growth of businesses without paid employees (by industry), number of workers who freelance, the divide between independent and contingent gig workers, the split of organizational spend across employees, non-payroll workers, and service providers, percentage of freelancers who say independent work is more secure than a traditional job, and the gig economy as a percentage of civilian employment. [7] The area of business 
education as well as the preparation of future managers in higher education with an emphasis on acquiring the competence of management diversity can also contribute significantly. Diversity management is also a question of occupational safety; ignoring its principles brings new risks at work and also other negative consequences. In particular, it is a protection against the risk of creating a negative brand meaning that can deter customers or partners from cooperating. Social responsibility is increasingly influencing brand perception by customers. [8]

\subsection{Dual education of juveniles}

Dual education is an effective preparation of students for their future profession. Dual education is based on a learning agreement between the employer and the student and a dual education agreement between the employer and the secondary vocational school. In the case of a minor student, the apprenticeship contract is signed by the legal representative. Combining practical teaching at the employer with theoretical education in secondary vocational school. It serves as an important tool for reducing youth unemployment, the main cause of which is the mismatch between the skills of school leavers and the needs of employers. Dual education has its strengths and weaknesses. Strengths include close cooperation between the school, the student and the employer, the acquisition of work habits directly in the production process, the acquisition of experience and qualifications. Also a high probability of obtaining an employment contract in a given company, teaching on new technologies directly at the employer, practically targeted curricula for individual departments and many others. [9] The biggest motivation for students is financial and material evaluation. The weaker aspects of dual education are excessive bureaucracy. In some cases, students do not pursue the profession due to a lack of working machines, skilled workers who should be devoted to them. Businesses often use pupils as cheap labour. [10] The teaching of dual education begins with the beginning of secondary vocational school. In the case of technical fields, a problem may arise on the part of the employer because the student does not yet have any theoretical knowledge in the field. Dual education also has its rules, which are set out in Act no. 61/2015 Coll. on Vocational Education and Training and on Amendments to Certain Acts. Based on these rules, the student acquires work habits, such as length of working hours, breaks and others. There is a great interest in dual education, mainly from employers, but also from students, as they will gain the necessary experience and practice in the field. In Slovakia, secondary vocational schools offer three-year apprenticeships with the receipt of an apprenticeship certificate and other disciplines ending with a school-leaving examination. Teaching in the dual education system takes place at weekly intervals, the theoretical part in one week at school, the practical part in the second week in the company, or in school workshops. Dual education in Slovakia takes place during the school year, exceptionally during the holidays. The state financially supports companies that create apprenticeships. The practical part of the final exam takes place at the workplace of practical training at the employer.

\subsection{Work conditions}

The employer may employ a natural person who has reached the age of 15 and has completed compulsory schooling. Every employer is obliged to know the requirements for the employment of juvenile employees, so as not to endanger health and ensure the development of mental and physical abilities. [11] The employment relationship is concluded on the basis of a written employment contract between the employer and the juvenile employee. Before concluding an employment contract, the employer must request the opinion of the juvenile employee's legal representative. Failure to deliver this statement 
will violate the provisions of the Labour Code. Every juvenile employee must undergo a medical examination before concluding an employment contract. This also applies in the case of transfer to another job. The employer must acquaint the juvenile employee with the work regulations, the collective agreement, the internal regulations and the possible risks involved in performing the work when starting work. A juvenile employee under the age of 16 has a maximum of 30 hours a week, even if he or she works for several employers. A juvenile employee over the age of 16 has a maximum working time of 37 to $1 / 2$ hours per week, even if he or she works for several employers. The working time of a juvenile employee may not exceed 8 hours in a 24-hour period. The employer is obliged to provide an employee whose work shift is longer than 6 hours with a break for rest and eating lasting 30 minutes. The employer is obliged to provide a juvenile employee whose change is longer than 4 and $1 / 2$ hours for a rest and eating break lasting 30 minutes. A juvenile employee may not be employed in underground work, in the extraction of minerals or in the excavation of tunnels and tunnels. Furthermore, he may not be employed in work with regard to anatomical, physiological and psychological peculiarities which are disproportionate, dangerous or harmful to his health. Lists of prohibited workplaces are established by a government regulation. The employer may not employ juvenile workers or work in which they are exposed to an increased risk of injury or in which their performance could seriously endanger the safety and health of others. In the case of persons under the age of 15, there is an exception when they can perform light work. This work must be characterized in that it does not endanger safety, health, development and school attendance. It is performing or co-performing at cultural, artistic, sporting events and advertising activities. At the request of the employer, the performance of light work of persons less than 15 years of age is approved by the relevant labour inspectorate in agreement with the authorized state administration body in the field of public health. The permit must specify the number of hours and the conditions under which light work is carried out.

\subsection{Illegal work - actual problem}

Employment is one of the main objectives of the European Union (EU) policies. In EU countries, several intervention programs have been implemented to increase employment and reduce the number of unemployed people. A necessary condition for economic development and raising living standards in Slovakia is to address employment issues in a way that would inter alia contribute to employment sustainability. [12, 13] Reducing the unemployment rate and related costs spent on unemployed job seekers from the state budget has long been one of the general goals not only of the Slovak Republic, but also of the entire European Union (EU) and its member states. [14] Work is an important part of every person. Many adolescents want to raise funds to provide for the basic necessities of life, but also to meet the needs of self-realization, socialization and creativity. [15] Nowadays, people want to do their job according to their wishes, desires and expectations. Their requirements are not always met, which is why many resort to illegal work. Illegal work is a negative economic and social phenomenon that also occurs in developed countries of the world. The tax burden, low level of legal awareness, regional differences and other shortcomings create suitable conditions for the abuse of labour law. Improper solutions can cause great damage to physical health, moral development, or truancy. [16] There are also big problems in finding a stable job with good pay conditions at a later age. The National Labour Inspectorate of the Slovak Republic annually prepares informative reports on the search for and detection of illegal work and illegal employment, including information on the number of illegally employed juveniles. Illegal work we can see also in international work environment. Buyens (2007) emphasizes such knowledge and skills as 
intercultural and interpersonal knowledge ; the ability to adopt other cultures ; the ability to establish contacts with local authorities, understand the local market, local legislative regulations ; ability to adapt to different national cultures internationally [17] According to the latest available information from 2018 on the website of the Labour Inspectorate, labour inspectors did not find any case of illegal employment of juvenile individuals in Slovakia. We obtained the above information on the basis of electronic communication directly with the employees of the National Labour Inspectorate of the Slovak Republic. We also encounter the problem of illegal work in the world. According to the World Report on Child Labour, approximately 168 million children work in the world. Most children are employed in agriculture (59\%), in construction, in small factories or on the street. Such cases in Europe occur mainly in Albania, Bulgaria, Georgia, Moldova, Montenegro, Romania, Serbia, Turkey and Ukraine. Nevertheless, European countries are better off than African states. [18] Most children in South Africa work on farms. [19] The problem of illegal work also affects states on the American continent. For example, North Carolina is one of 41 states where they require work permits from employees under the age of 18 . Based on a study carried out in that country, it was found that $40 \%$ of juveniles worked in breach of work permit requirements, and 2 to $11 \%$ worked in breach of hourly conditions. Children aged 14 to 15 violated the daily standard, i.e. they worked even after $7 \mathrm{pm}$. Adolescents under the age of 18 also performed night work. [20] The United Nations of 1981 defines a juvenile as a person between the ages of 15 and 24 for statistical purposes (UN, 1981). Member States may use a different age limit. In many countries, there is no suitable system to support youth employment. According to 2013 data, Europe registered more than 5.5 million unemployed adolescents, exceeding $46 \%$ in Greece and $44.4 \%$ in Spain and 16\% in the Russian Federation. [21] The latest data from November 2018 show a decrease in the youth unemployment rate to 3.4 million. Youth unemployment in the United States is $14.5 \%$. The data shows officially registered juveniles on the job market. [22] In 2018, youth unemployment among 16- to 19-year-olds in the United States was approximately 11.6 million people. In contrast, countries with the lowest youth unemployment include Japan (4.3\%), Hong Kong (5.7\%) and Germany (6.7\%). [23]

\section{Research results and discussion}

The aim of the research was to analyse the current problems of youth employment, compliance with contractual conditions, safety at work and the impact of dual education. We focus on students of secondary vocational schools, aged 15 to 18 . We used the interview which were conducted with students from the field of gastronomy / hospitality), medical school, technical schools and with external consultants - masters of vocational training at a secondary vocational school, managers in companies involved in dual education. Managers do not want to be appointed. As part of their professional activities, secondary vocational school students prepare for their future careers in various companies and operations. Many of them work part-time in addition to school. The method of questioning through an anonymous questionnaire is also used to analyse the given problems, due to the possibility of obtaining the subjective statements of the respondents. The interrogation method is used mainly because personal contact with each respondent is not necessary and the required amount of data is obtained in a short time interval. Based on the interviews, we found that not all terms and conditions are always met. In most establishments in the hotel and gastronomy sector, the emphasis is on observing working hours of 30 hours per week, but also on observing work breaks. In agreement with the employer, in exceptional cases, when students work a little longer one day, they end up the next day or are paid a certain percentage of their salary. Students are often used for various jobs that are not within their competence and that are not specified in the employment 
contract. In case of any problem, the students themselves are responsible. Personal protective equipment must be provided by themselves, at their own expense. If accommodation is needed, it is not always provided at the level. Few hotels offer it during the period of professional practice for students; it is not a matter of course. One of the problems is bullying in the workplace by older colleagues in the form of ridicule of appearance, weight, humiliation in front of others. Many times they are considered inferior and inferior. When receiving a tip, they must hand over the entire amount to their superior. Students of the medical school also commented on this issue, who mentioned many positives, but also negatives within the professional practice. They gain experience in hospitals, hospices and retirement homes. Working hours and breaks are strictly adhered to. A common problem is the lack of protective equipment such as gloves, drapes, disinfection and others - possible menial work, arrogance on the part of some colleagues. Much depends on the medical team in the individual departments. Students also meet with willingness, interest from their superiors in various actions and explanations. Appropriately, they are praised by the elderly in hospitals and retirement homes. If the management is satisfied with their work, they are also allowed to work during the holidays. Students who carry out professional activities in industrial areas state strict adherence to the schedule of set working hours, breaks, during the performance of professional practice in companies. The employer provides them with personal protective equipment used at work. There is also a contribution for food, transport scholarship in the framework of dual education. For productive work they are financially evaluated according to the given year. All items are listed in the apprenticeship contract as well as in the dual education contract, which are annexed. Illegal work, which is based on an oral agreement, is also an occasional soughtafter option for juveniles. In case of misunderstanding, there is a problem with proving the agreed conditions. They cited better financial improvements and freer working hours as an advantage. Interviews with external consultants show that the demand is higher than the number of graduates ending years. Especially in the engineering industries, departments such as toolmaker, mechanic, adjuster, $\mathrm{CNC}$ machine programmer. Adolescents have many times higher financial demands for job evaluation than they are provided by their employer, they lack flexibility, they are reluctant to continue their education. They would like everything right away. They lack patience to go through probation, gain experience and thus work towards a higher financial and professional evaluation. Managers of several companies stated that if the employer is satisfied with the student's work during the performance of professional activities in his company, he will often offer him the opportunity to earn an employment contract during the summer holidays and after graduation. They see great potential in dual education, because students and graduates already have some work experience, know the work environment and the team of coworkers. Although they are formed directly in the company, they still cannot perform any work, retraining is needed. A new generation is coming out of schools, which cannot function without mobile phones and social networks, which often causes inattention at work. The employer sees this as a modern problem for juveniles. The questionnaire was aimed at determining compliance with contractual working, safety and protective conditions in the performance of work in the framework of dual education / professional practice and in other work activities - brigades. The questionnaire was filled in by 258 respondents. The results show that employers pay attention to compliance with conditions such as a professional instructor, time schedule and compliance with working hours, a maximum of 7 hours per day. To a large extent, $80 \%$ of the respondents underwent a medical examination, up to $98.4 \%$ of the respondents were acquainted with the work rules and possible risks, which means that they are sufficiently informed about the performance of work and thus reduces possible injuries. Requirements for personal protective equipment were met; a lower number of students reported work on standby (30\%), overtime $19 \%$. 
Increased stress was reported by $25 \%$ of respondents, mainly due to the amount of work, lack of time, arrogance and arrogant behaviour on the part of superiors. Respondents are not exposed to harmful radiation when performing work in dual education / professional practice; $17.1 \%$ of students reported contact with dangerous chemical and biological substances. $26.4 \%$ were exposed to a large temperature difference, $30.2 \%$ of respondents reported excessive noise and vibration. $23 \%$ of respondents worked with heavy loads.

Regarding part-time work, young people most often work $(58.9 \%)$ on a part-time agreement for students (maximum 20 hours per week). $25.6 \%$ of respondents admitted to work without an agreement, within the brigade. It's an alarming number now. Students are not aware of the seriousness of the situation, for example, in the event of an accident; the employer will not reimburse the expenses incurred. In almost $60 \%$ of cases, employers did not require the opinion of a legal representative when concluding an employment contract for a juvenile student. This is a violation of legal terms and conditions. Juveniles most often worked in the field of study (41.9\%), followed by hospitality and gastronomy (28.7\%). 13 were identified by adolescents, in retail and wholesale (13.2\%). As part of the other option, students mentioned a call centre, fitness centre, trucking, entertainment industry, brigade harvest season and more. Adolescents expressed differences in the application of safety and health protection during dual education / professional practice and brigades. Adherence to the break was reported by $79.1 \%$, in dual education / professional practice $93 \%$, working time in part-time jobs was $72.9 \%$ and in the process of education $89.1 \%$. As many as $38.8 \%$ of respondents have no problem accepting work without an employment contract, only on the basis of an oral agreement. The most common reason for accepting such work are better payment terms than stated by $23,2 \%$ of respondents. Pupils have a negative perception of too much work done, which has been disproportionately or low. They also state that some work activities were carried out in all weathers, e.g. when distributing leaflets and when working on construction sites. The performed analysis of current problems of employment of juveniles confirmed the initial presumption of non-compliance with the conditions stipulated by law and the low information level of juveniles. The main problems are that adolescents often do not undergo a medical examination; they are not always familiar with the rights and obligations arising from the employment relationship. Employers also violate the obligation to request a statement from a legal representative before starting work, there is night work and non-compliance with breaks at work. These findings only confirmed that employers do not always comply with the legal conditions in relation to juvenile employees. This may be partly due to ignorance of some employment legislation. The reason employers illegally employ minors is often to save on labour costs. Juvenile employees are a cheaper alternative than employees working on a permanent basis. It can be assumed that not all competent persons in companies will master the legal legislation in the field of employment within all its limits. This can also be another reason why the law is broken. Based on a survey conducted through inquiries, we found that the information level of juvenile employees in the field of employment is low. They do not know what rights and obligations they have with the establishment of an employment relationship between them and the employer. It can be assumed that even their parents or. Legal guardians do not have sufficient knowledge about the employment of juveniles and thus cannot help them. Proposals for measures to eliminate shortcomings in the employment of juvenile workers are summarized in five points. We propose that an issue that speaks about the legal status of a juvenile employee in the Slovak Republic be included in the subject curriculum. We also recommend the retraining of interested employees from companies participating in dual education to work with young people. It would be It would be useful tightening up inspections by labour inspection. More frequent inspections by state administration bodies with a focus on the work of juvenile employees will respect the law by employers. Any violation of the provisions of the Labour Code is considered a violation of labour law 
regulations, which may be sanctioned by a fine of up to EUR 100,000 by the Labour Inspectorate.

\section{Conclusions}

Work is defined in economics as one of the factors of production. It is determined by purposeful human activity, focused on the creation of goods and services that satisfy human needs. Human work is formed and created in a complex system in which the nature of work is determined through a system of decisive factors. These are socio-economic, ethicalaesthetic, biological anthropological and other factors of technology and technology of production and services, or even factors of corporate culture. Occupational safety and health at work is very important. A special group of employees, which also includes juveniles, requires specific attention to safety and health at work. Requirements in the field of safety and health at work are clearly formulated in the applicable legislation, but it depends only on each employee of the company how the regulations of legal regulations implemented in everyday work. We found that juveniles have low awareness of the position of the juvenile employee in the labour market and that employers are violating their legal obligations in relation to juveniles. With the proposals, we want to eliminate the current problems of youth employment. We plan to focus further research in this area on the working conditions of juveniles under the influence of the COVID 19 pandemic, as we assume that the identified shortcomings may be exacerbated in a crisis situation.

This paper is an output of the Science Project No. 4/PEDAS/2019 Sustainable Human Resources Management in Era of Globalization and VEGA No. 1/0619/20 VEGA No. 1/0619/20 Fundamental research of quantitative and qualitative determinants of innovation potential and innovation performance of a company in relation to increasing its competitiveness; VEGA no. 1/0064/20. Behaviorism in a socially responsible communication strategy of enterprises

\section{References}

1. Sabo, M., Holub, D. (2010). Základy práva pre ekonómov. Bratislava: Iura Edition.

2. Barancová, H., Schronk, R. (2009). Pracovné právo. Bratislava: Sprint.

3. Krošlák, D., Nevolná, Z., Olšovská, A. (2014). Podnikatel'ské právo. Bratislava: Wolters Kluwer.

4. Hodgins, M., MacCurtain, S., McNamara, PM. (2020). Power and inaction: why organizations fail to address workplace bullying. International Journal of Workplace Health Management, 13(3), 256-290.

5. Lombardo, M. M., Eichner, R. W. (2006). For your improvement. A guide for development and coaching. For learners, managers, mentors, and feedback givers. Lominger International.

6. Rodrigues, MA, Sa, A., Masi, D., Oliveira, A., Boustras, G., Leka, S., Guldenmund, F. (2020). Occupational Health \& Safety (OHS) management practices in micro- and small-sized enterprises: The case of the Portuguese waste management sector. Safety science, 129, Article Number: 104794.

7. Culkin, B. (2019). Is Platform Capitalism Sustainable? Digital Business Models, OnDemand Labor, and Economic Growth. Journal of Self-Governance and Management Economics, 7(1), 31-36.

8. Valaskova, K., Kliestikova, J., Krizanova, A. (2018). Consumer Perceptions of Private Label Products: An Empirical Study. Journal of Competitiveness, 10(3), 149-163. 
9. Kováč, L., Žitnáková, M. (2015). Systém duálneho vzdelávania. Štátny inštitút odborného vzdelávania.

10. Petanovitch, A., Schmid, K., Bliem, W. (2014) Faktory úspechu pri duálnom vzdelávaní.Wien. Wirtschaftsförderungsinstitut der Wirtschaftskammer.

11. Pohorelá, P. (2019, July 5). Zamestnávanie mladistvých (do 18 rokov) v roku 2019. Retrieved from: https://www.podnikajte.sk/pracovne-pravo-bozp/zamestnavanieneplnoletych-do-18-rokov

12. Vrbka, L., Lutan Petre, G. A. (2019). Evaluation of the effects of intervention programs for unemployed: An overview of methods, Ekonomicko-manazerske spektrum, 13(2), 56-67.

13. Svabova, L., Durica, M., Kramarova, K., Valaskova, K., Janoskova, K. (2019). Employability and Sustainability of Young Graduates in the Slovak Labour Market: Counterfactual Approach. Sustainability, 11(16), 4462.

14. Svabova, L., Durica, M., Kliestik, T. (2019). Modelling the Costs of Unemployment for Young Graduates in Slovakia: A Counterfactual Approach. Politická Ekonomie, 67(5), 552-566.

15. Trevino, L. K., Weawer, G., Gibson, D., Troffler, B.(1999). Managing ethics and legal compliance: What works and what hurts. California Management Review, 41(2), 131+-

16. Fagan, J. (1997). Legal and illegal work - Crime, Work and Unemployment. In BA Weisbrod \& JC Worthy (Eds.), Urban Crisis: Linking Research to Action: Proceedings of the International Conference (pp. 33 - 80). Evanston : Northwestern University Press.

17. D. Buyens. (2007). Strategic HRM : The threee pillar model : A blueprint for future $H R$. Conference on International HRM, Santa Fe, NM.

18. Čonka, P. (2017). Legal Adjustment of illegal employment of children in Slovak republic. In P. Hajek, O. Vit, P. Basova, M. Krijt, H. Paszekova, O. Souckova \& R. Mudrik (Eds.), Innovations in Science and Education : International Conference of Central-Bohemia-University (pp. 566-569). Prague: Central Bohemia University.

19. Senou, R.B., Degilla, J., Adjobo, E. CH., Djssou, A. P. M. (2019). Blockchain for Children labour Decrease in Cocoa Production in West and Central Africa. Proceedings of the Conference Manufacturing Modelling, Management and Control (pp. 2710-2715). Amsterdam:Elsevier.

20. Santo, J., Bowling, M. J., Harris, T. A. (2010). Effects of Work Permits on Illegal Employment Among Youth Workers: Findings of a School-Based Survey on Child Labor Violations. American Journal of Public Health, 100(4), 635-637.

21. Shiplina, T., Vasiutina, E., Mosalev, A., Nanyunja, R. (2018). Modern problems of youth in the labour market: global trends and Russian specifics. In R. Maloletko, N. Rupcic \& Z. Baracskai (Eds.), Proceedings of the 34th International Scientific Conference on Economics and Social Development (pp. 765-773). Varazdin: Development \& Enterpreneurship Agency.

22. Jacobs, E. (2014, May 22). Twelve ways to fix youth unemployment crisis. Retrieved from : $\quad$ https://www.brookings.edu/research/twelve-ways-to-fix-the-youthunemployment-crisis/

23. Kluve, J., Puerto, S., Robalino, D., Romero, J. M., Rother, F., Stoterau, J., Weidemkaff, F., Witte, M. (2019). Do youth employment programs improve labour market outcomes? A quantitative review. World Development, 114, 237-253. 